\title{
Effect of Time and Reaction Speed on Making Liquid Soap in Terms of Viscosity and Density Values
}

\section{Pengaruh Waktu dan Kecepatan Reaksi pada Pembuatan Sabun cair Terhadap Nilai Viskositas dan Massa Jenis}

\author{
Erna Astuti a,1, Aster Rahayu a,2,* Endah Sulistiawati a,3, Baiq Alma a , Sandra Devi a \\ ${ }^{a}$ Program Studi Teknik Kimia, Fakultas Teknologi Industri, Universitas Ahmad Dahlan, Kampus IV, Jl. Ringroad selatan, Bantul, D.I. Yogyakarta, 555191 \\ ${ }^{1}$ erna.astuti@che.uad.ac.id*; ${ }^{2}$ aster.rahayu@che.uad.ac.id *; ${ }^{3}$ endahsulistiawati@che.uad.ac.id \\ * corresponding author
}

\section{ARTICLE INFO}

\section{Article history}

Received Nopember 30, 2019

Revised January 27, 2021

Accepted August 13, 2021

\section{Keywords}

Minyak kelapa

Sabun

Saponifikasi

Viskositas

\section{ABSTRACT}

Soap is a product from the hydrolysis of fats into fatty acids and glycerol under alkaline conditions, known as the saponification process. Many factors affect the saponification process to produce liquid soap with proper quality, including viscosity and density values. Saponification time and stirring speed are factors that affect the soap quality to be observed. Using strong bases and strong acids from electrolysis machines as well as coconut oil as a natural comperland are the innovations in this study. The results obtained are liquid soap in accordance with SNI 06-4085-1996, where the expected density ranges from (1.01-1.10 gr/cm3) and viscosity (400-20000 cP). Based on the current results, the most optimal results in accordance with SNI 064085-1996 are 24 hours for saponification time and stirring for 40 minutes, with a density of $1.083 \mathrm{gr} / \mathrm{ml}$ and viscosity of $482.0755 \mathrm{cP}$.

This is an open access article under the CC-BY-SA license.

\section{Pendahuluan}

Penggunaan sabun sudah tidak asing lagi dalam kehidupan sehari-hari. Perkembangan sabun sangatlah pesat terbukti dengan semakin banyaknya jenis sabun yang beredar di pasaran. Sabun dibuat berdasarkan pada proses saponifikasi yang merupakan hidrolisis lemak menjadi asam lemak dan gliserol dalam kondisi basa. Secara umum sabun merupakan senyawa natrium atau kalium yang mempunyai rangkaian karbon yang panjang dan kemudian direaksikan dengan asam lemak khususnya trigliserida yang berasal dari minyak nabati atau lemak hewani [1]. Penelitian yang menggunakan berbagai sumber asam lemak pada pembuatan sabun telah dilakukan, diantaranya limbah lemak industri kulit [2], minyak jarak [3], minyak jelantah [4] dan minyak biji kakao [5]. Jika basa yang digunakan adalah $\mathrm{NaOH}$, maka produk reaksi berupa sabun keras (padat), sedangkan bila basa yang digunakan berupa $\mathrm{KOH}$, maka produk reaksi berupa sabun cair.

Berbagai pembaharuan terhadap sabun cair terus dilakukan mulai dari pemilihan bahan baku yang merupakan bahan kimia yang tidak memberikan efek samping terhadap pemakai hingga mengganti bahan baku dengan bahan baku alami. Salah satu contohnya adalah penggunaan pewarna dan aroma alami daun pandan, jeruk nipis, lidah buaya, dan sebagainya. Penelitian mengenai hal tersebut telah mulai dilakukan [6-9]. Penggunaan bahan dasar alami seperti minyak kelapa, virgin coconut oil (VCO), minyak jarak, minyak biji kelor bahkan minyak jelantah telah banyak dilakukan [10-13]. Beberapa penelitian yang telah dilakukan dengan menggunakan bahan dasar minyak kelapa, akan tetapi masih menggunakan basa kuat umum seperti $\mathrm{NaOH}$ dan $\mathrm{KOH}$ [14-16]. pada penelitian ini, penggunaan asam dan basa yang umum akan menggunakan air yang telah diatur 
keasaman dan basanya. Pada proses pembuatan sabun, pengadukan merupakan salah satu parameter yang mempengaruhi kualitas sabun yang dihasilkan [17]. Pada penelitian ini akan dipelajari pengaruh kecepatan dan waktu reaksi pada pembuatan sabun cair dari minyak kelapa terhadap kualitas sabun yang dihasilkan.

\section{Metodologi Penelitian}

\subsection{Bahan Baku dan Peralatan}

Bahan yang digunakan antara lain texapon, Asam sitrat, $\mathrm{NaCl}$, sodium sulfat, Propilen glikol/PG, pewangi, pewarna, Ethylene diamine tetra acetic acid/EDTA, Akuades, comperland, Basa kuat, dan Asam kuat buatan sendiri dari mesin elektrolisis. Setelah dianalisis, basa kuat mempunyai kadar Natrium 3493,45 mg/liter, dan Asam kuat 747,29 mg/liter. Peralatan yang digunakan antara lain pengaduk, $\mathrm{pH}$ meter, inkubator dan peralatan gelas laboratorium.

\subsection{Analisis Sabun}

Untuk mengetahui kualitas Sabun yang telah dihasilkan, maka dilakukan pengujian terhadap beberapa parameter nilai berdasarkan SNI 06-4085-1996. Diantaranya uji aktifitas antibakteri, uji organoleptik, nilai $\mathrm{pH}$ serta viskositas. Uji aktifitas antibakteri yang dilakukan, suspensi bakteri diambil dengan cotton swab steril dan disebar pada permukaan media Mueller Hinton Agar (MHA). Selanjutnya pada media MHA dibuat lubang berdiameter $6 \mathrm{~mm}$ dan diisi dengan sampel sebanyak $50 \mu \mathrm{L}$. Dibiarkan selama 60 menit sampai sampel meresap setelah itu diinkubasi selama 24 jam pada suhu $37^{\circ} \mathrm{C}$. Zona hambat yang terbentuk diukur diameternya [18].

\section{Hasil dan Pembahasan}

\subsection{Kecepatan dan Waktu Pengadukan}

Dalam langkah awal pembuatan sabun cair, bahan yang dibutuhkan seperti texapon, sodium sulfat, minyak kelapa, asam sitrat dan aquades dicampur hingga homogen. Setelah tahap homogenisasi tersebut dilanjutkan dengan tahap pengadukan dengan menambahkan bahan tambahan lainnya seperti EDTA, PG, pewarna serta parfum sehingga semua bahan yang digunakan dapat tercampur dengan sempurna. Pada tahap ini, pengaruh kecepatan pengadukan diamati untuk mendapatkan hasil yang lebih baik dan konsisten. Pada tahap ini dilakukan variasi metode pengadukan yaitu pengadukan tidak beraturan dan pengadukan beraturan dengan kecepatan yang ditentukan. Hasil yang diperoleh pada pengadukan tidak beraturan yaitu densitas sebesar 1,1125 $\mathrm{gr} / \mathrm{ml}$ dan nilai viskositas sebesar $562,159 \mathrm{cP}$ serta nilai $\mathrm{pH} 8$, sedangkan pada kecepatan pengadukan beraturan diperoleh densitas sebesar $1,1007 \mathrm{gr} / \mathrm{ml}$ dan nilai viskositas sebesar 482,5953 $\mathrm{cP}$ serta nilai $\mathrm{pH}$ 8. Sehingga dapat disimpulkan bahwa kecepatan pengadukan beraturan lebih bagus dan mendekati standar SNI. Hal ini disebabkan karena pada saat pengadukan dengan kecepatan beraturan, semua bahan pembuatan sabun dapat tercampur dengan merata.

Observasi waktu pengadukan dilakukan dengan menggunakan variasi 20, 30, 40, 50, dan 60 menit. Dari hasil uji densitas terhadap setiap variasi yang dilakukan rata-rata memenuhi standarisasi dari SNI berturut-turut yaitu $1,022 \mathrm{gr} / \mathrm{mL}, 1,026 \mathrm{gr} / \mathrm{mL}, 1,065 \mathrm{gr} / \mathrm{mL}, 1,102 \mathrm{gr} / \mathrm{mL}$, dan 1,105 $\mathrm{gr} / \mathrm{mL}$. Sedangkan untuk nilai viskositas semakin lama waktu pegadukan menghasilkan nilai viskositas yang semakin tinggi. Nilai viskositas berturut-turut yaitu 61,967 cP, 96,407 cP, 484,453 cP, 574,010 cP, 660,596 cP. Untuk nilai pH diperoleh sebesar 10, 10, 10, 8, 8. Selanjutnya untuk rata rata nilai uji bakteri berturut turut yaitu $11,917 \mathrm{~mm}, 12,167 \mathrm{~mm}, 18,667 \mathrm{~mm}, 10,583 \mathrm{~mm}$, dan 13,750 mm seperti terlihat pada Tabel 1 . 
Tabel 1. Hasil uji aktivitas antibakteri sampel sabun cair dan sampel komersial

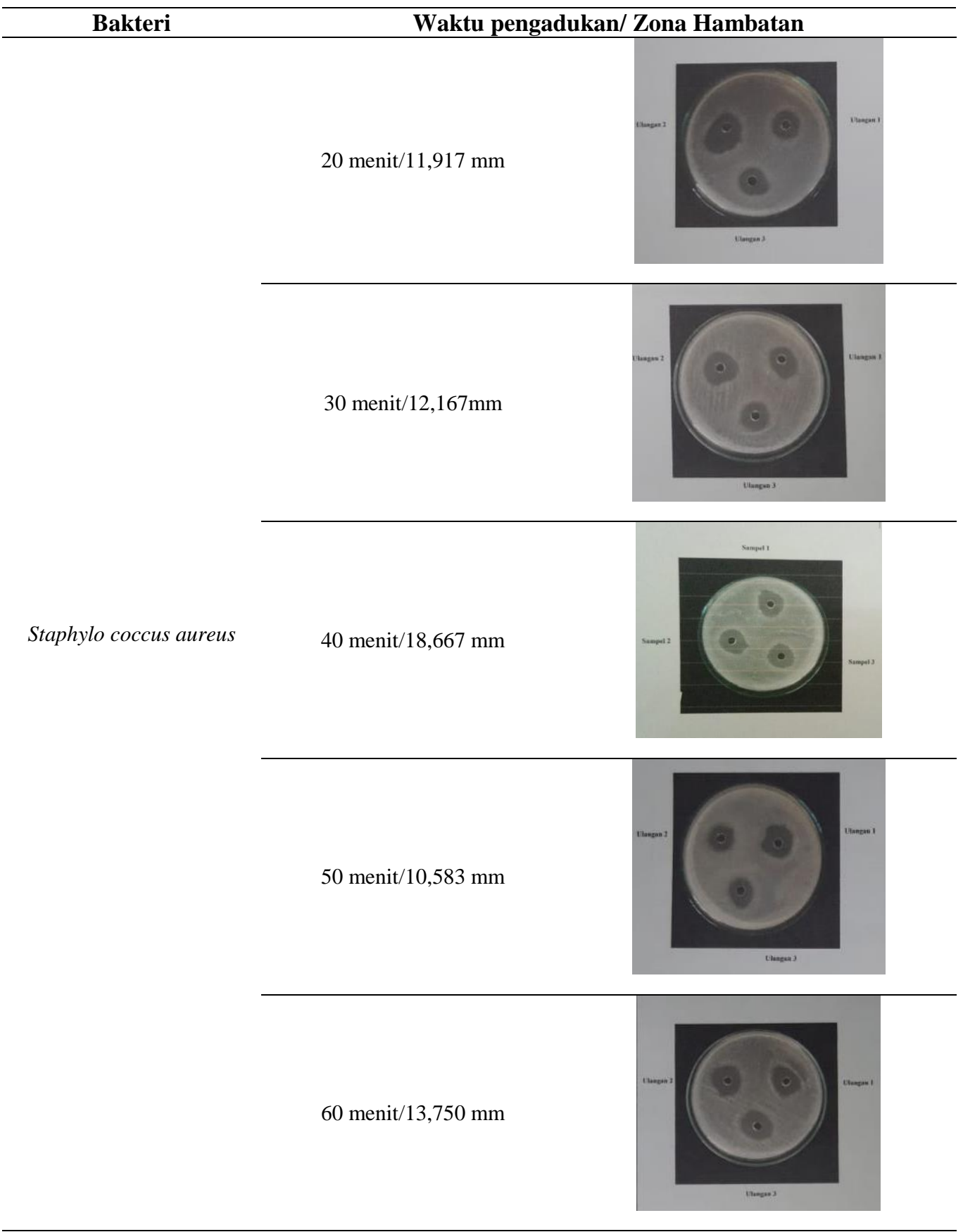

Hasil uji anti bakteri yang didapatkan tersebut menunjukkan bahwa sabun cair dapat menghambat aktifitas bakteri Staphylococcus aureus. Data tersebut menunjukkan bahwa waktu pengadukan 40 menit yang mendekati standar SNI, baik dari nilai densitas, viskositas, $\mathrm{pH}$ maupun uji bakterinya. Hal ini membuktikan bahwa waktu pengadukan juga berpengaruh terhadap kekentalan produk sabun yang dihasilkan. Densitas dan viskositas sabun cenderung naik seiring dengan bertambahnya waktu pengadukan dalam reaksi penyabunan. Ini disebabkan oleh adanya partikel $\mathrm{H}_{2} \mathrm{O}$ yang mulai menguap sehingga menyebabkan kandungan air pada sabun akan berkurang sehingga sabun menjadi mengental. Sedangkan untuk nilai $\mathrm{pH}$, semakin bertambahnya waktu pengadukan dapat menyebabkan turunnya $\mathrm{pH}$ sabun yang dihasilkan. Berdasarkan penelitian sebelumnya, semakin lama waktu pengadukan menyebabkan waktu interaksi antara minyak dan alkali semakin besar, maka reaksi akan mendekati kesetimbangan sehingga residu alkali akan semakin rendah yang menyebabkan sabun tidak terlalu basa [19]. Adapun hasil tersebut dapat dilihat pada Gambar 1 dan 2. 


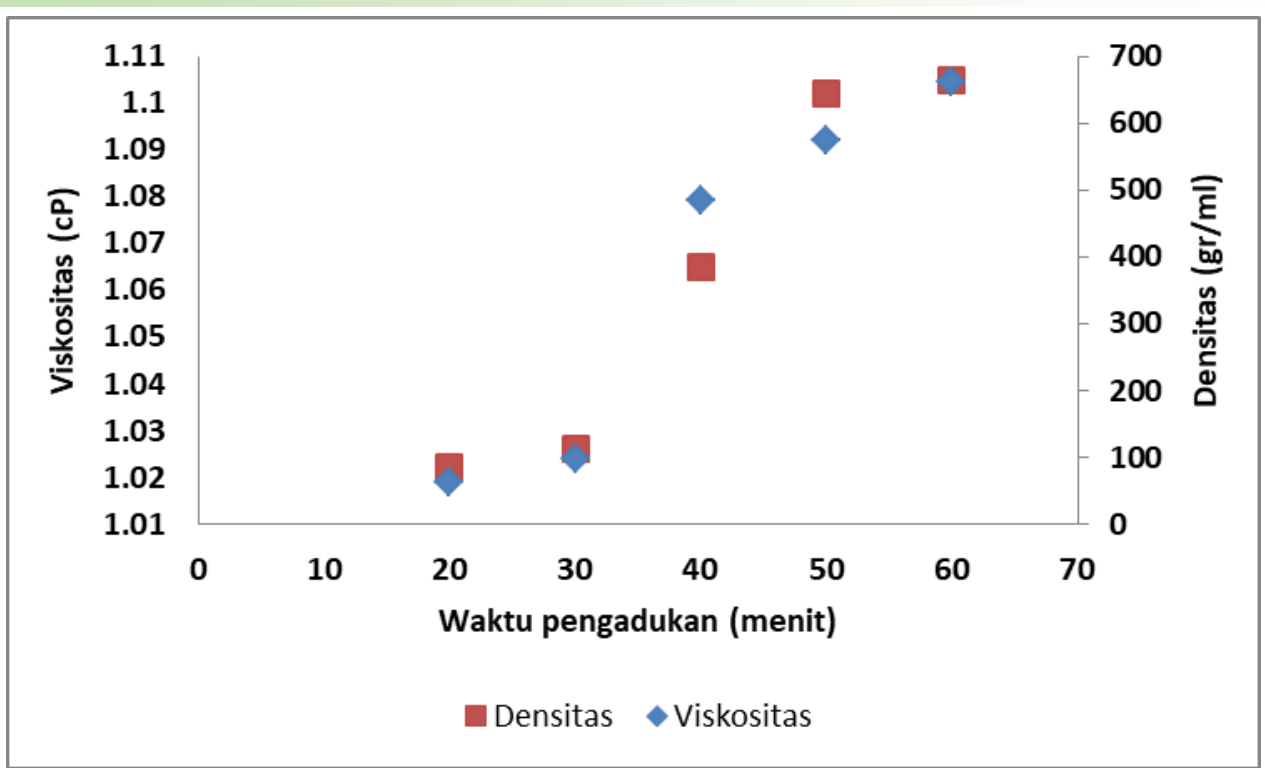

Gambar 1. Pengaruh waktu pengadukan terhadap nilai viskositas dan densitas

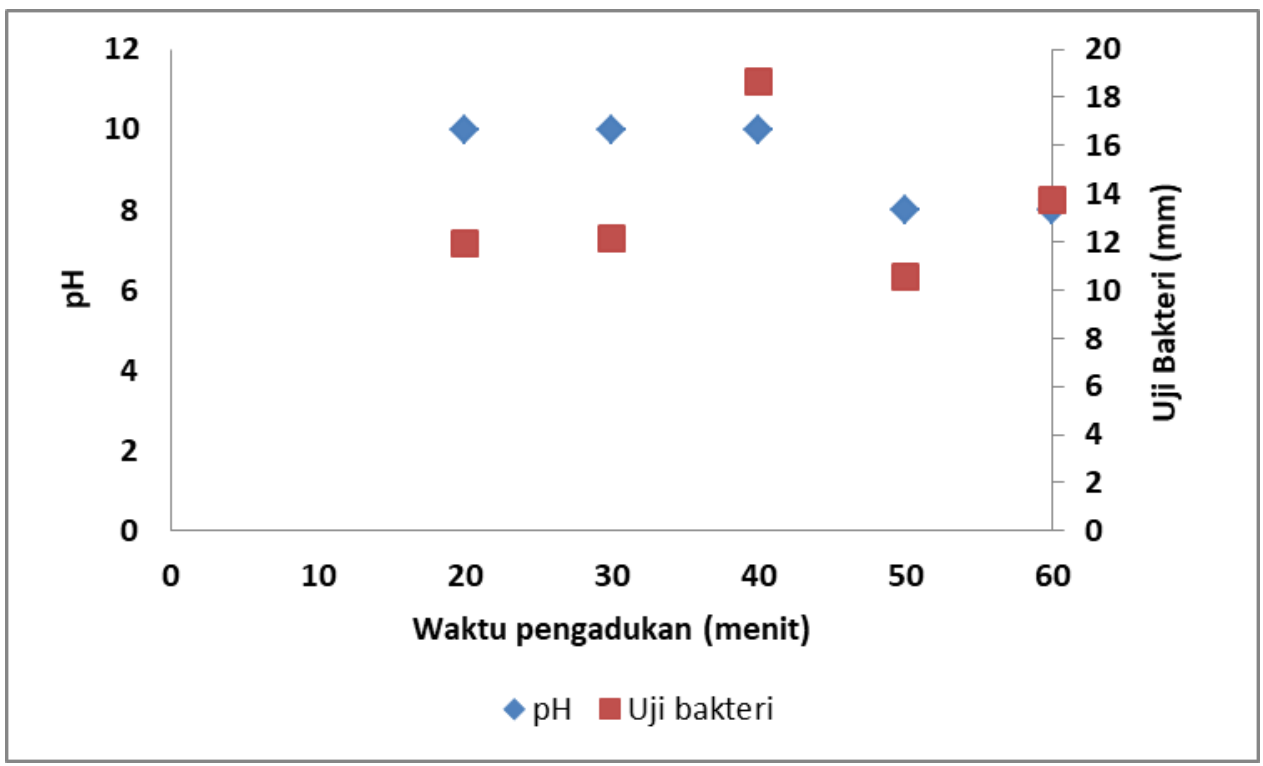

Gambar 2. Pengaruh waktu pengadukan terhadap nilai $\mathrm{pH}$ dan uji bakteri

\subsection{Waktu saponifikasi}

Pada prinsipnya sabun dihasilkan dengan adanya peristiwa penyabunan atau saponifikasi. Proses saponifikasi terjadi akibat reaksi antara lemak dengan basa. Lama waktu yang diperlukan pada proses saponifikasi dapat dilihat pada tabel 2. Semakin lama waktu yang dibutuhkan dalam proses saponifikasi menghasilkan sabun cair dengan viskositas yang lebih besar juga. Waktu saponifikasi yang digunakan dalam penelitian ini yaitu 12 jam dan 24 jam. Keduanya mengasilkan data yang memenuhi standar SNI, tetapi waktu saponifikasi 24 jam lebih baik dibandingkan dengan waktu saponifikasi 12 jam seperti terlihat pada Gambar 3. Hal ini disebabkan karena dalam waktu saponifikasi 12 jam larutan sabun belum sepenuhnya tersaponifikasi, ditinjau dari produk sabun yang masih banyak berupa busa, teksturnya juga lebih kasar dan lebih encer dibandingkan dengan waktu saponifikasi 24 jam. Dalam waktu saponifikasi 12 jam diperoleh densitas rata-rata 1,053 $\mathrm{gr} / \mathrm{mL}$ dengan viskositas $477,7760 \mathrm{cP}$ serta $\mathrm{pH}$ sebesar 8, sedangkan dalam waktu saponifikasi 24 jam diperoleh densitas rata-rata 1,0734 gr/mL dengan viskositas $482,2949 \mathrm{cP}$ serta $\mathrm{pH}$ sebesar 8 . Ini membuktikan bahwa semakin lama waktu saponifikasi maka nilai densitas dan viskositasnya akan semakin besar. 


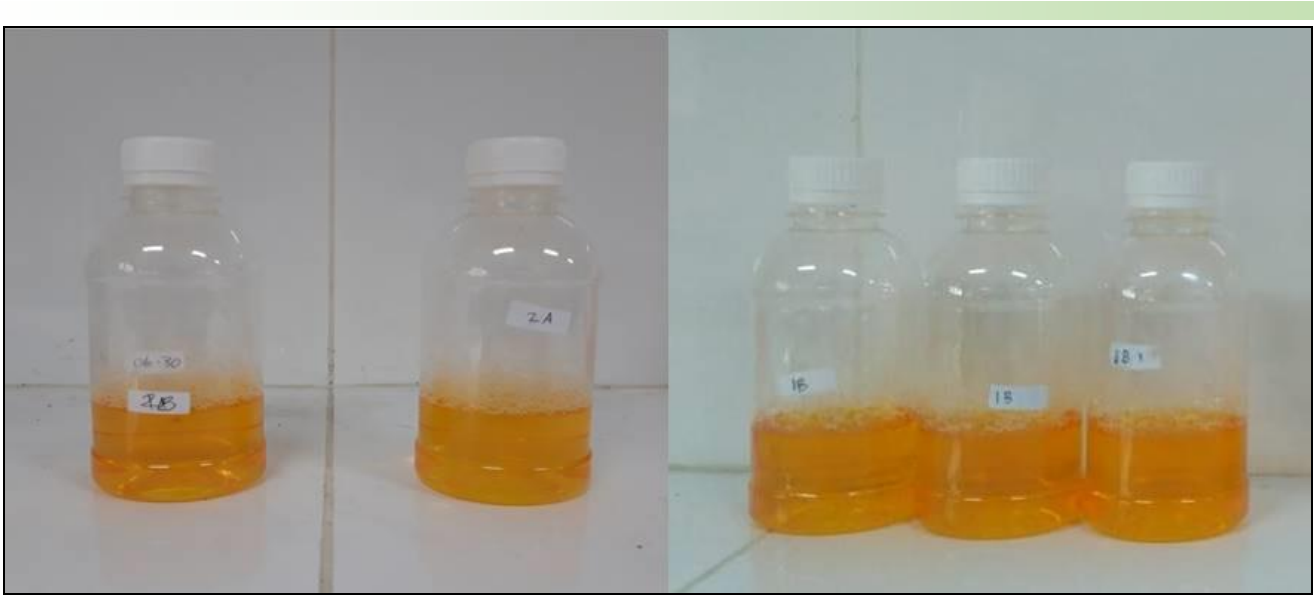

(a)

(b)

Gambar 3. Pengaruh waktu saponifikasi. (a) saponifikasi 12 jam, (b) saponifikasi 24 jam

\subsection{Repeatability}

Untuk mengetahui ketepatan dalam pembuatan sabun cair khususnya metoda yang digunakan, maka dilakukan uji repeatability. Uji ini dilakukan dengan melakukan pengulangan dalam pembuatan sabun cair dengan menggunakan kondisi metoda yang optimum yaitu pengadukan searah dengan kecepatan beraturan, waktu saponifikasi 24 jam dan pengadukan selama 40 menit. Konsistensi pada hasil sabun cair sangat dibutuhkan jika ingin memproduksi sabun cair tersebut pada skala yang lebih besar. Dari hasil pembuatan sabun, didapatkan nilai reproduksibilitas $(n=5)$ sebesar 3,30\% dan 3,67\% berdasarkan hasil nilai densitas dan viskositas sabun yang dihasilkan. Menurut persamaan Horwitz dimana standar deviasi relatif untuk sampel dengan kadar satu per seribu RSD nya adalah $<3 \%$. Berdasarkan nilai yang diperoleh masih di luar dari batas interval repeatability.

\subsection{Perbandingan dengan nilai SNI}

Dari semua percobaan yang telah dilakukan, diperoleh hasil akhir yang mendekati sabun SNI dan sabun komersial yaitu dengan metode pengadukan searah dan kecepatan beraturan, serta waktu saponifikasi 24 jam dan pengadukan selama 40 menit. Parameter pengujian dilakukan tidak hanya berdasarkan nilai densitas dan viskositas, tetapi juga dengan membandingkan nilai uji organoleptik. Uji organoleptik meliputi bentuk, bau dan warna yang dilakukan dengan tujuan untuk melihat respon konsumen terhadap tingkat kesukaan sabun yang dihasilkan. Pada pengujian organoleptik ini dilakukan pada panelis sebanyak 23 orang. Perbandingan sabun yang dihasilkan dengan sabun komersil serta nilai pada standar SNI dilihat pada Tabel 2.

Tabel 2. Perbandingan data hasil penelitian dengan nilai SNI

\begin{tabular}{cccc}
\hline Parameter & SNI & Data penelitian & Komersial \\
\hline Keadaan: & & & \\
Bentuk & Cairan homogen & Cairan homogen & Cairan homogen \\
Bau & Khas & Khas & Khas \\
Warna & Khas & Khas & Khas \\
\hline Densitas & $1,01-1,10 \mathrm{gr} / \mathrm{ml}$ & $1,083 \mathrm{gr} / \mathrm{ml}$ & $1,04 \mathrm{gr} / \mathrm{ml}$ \\
Viskositas & $400-20000 \mathrm{cP}$ & $482,0755 \mathrm{cP}$ & $483,0558 \mathrm{cP}$ \\
\hline
\end{tabular}

\section{Kesimpulan}

Hasil yang didapatkan pada penelitian ini adalah sabun cair yang dibuat dengan menggunakan minyak kelapa sebagai comperland alami telah sesuai dengan SNI 06-4085-1996, dengan nilai repeatibily terhadap nilai viskositas dan densitas sebesar 3,30\% dan 3,80\%. Nilai rata-rata densitas dan viskositas telah sesuai dengan yang diharapkan yaitu $\left(1,01-1,10 \mathrm{gr} / \mathrm{cm}^{3}\right)$ dan $(400-20000 \mathrm{cP})$. Berdasarkan hasil yang ada, hasil yang paling optimal sesuai dengan SNI 06-4085-1996 adalah pada metode pengadukan searah dan kecepatan beraturan, serta waktu saponifikasi 24 jam dan 
pengadukan selama 40 menit. Dengan densitas sebesar 1,083 $\mathrm{gr} / \mathrm{ml}$ dan viskositas yang dihasilkan sebesar $482,0755 \mathrm{cP}$.

\section{Ucapan Terimakasih}

Penulis mengucapkan terima kasih kepada Lembaga Penelitian dan Pengabdian Kepada Masyarakat (LPPM) Universitas Ahmad Dahlan yang telah mendanai penelitian ini, serta kepada M. Tamrin dan Eko Susilowati, selaku Laboran Teknik Kimia UAD dan para mahasiswa yang telah membantu penelitian ini.

\section{Daftar Pustaka}

[1] R. Hasibuan, F. Adventi, R. P. Rtg, Pengaruh Suhu Reaksi, Kecepatan Pengadukan Dan Waktu Reaksi Pada Pembuatan Sabun Padat Dari Minyak Kelapa (Cocos Nucifera L.). Jurnal Teknik Kimia USU, Vol. 8, No. 1, 2019.

[2] P. Naomi, A.M. L. Gaol, and M.Y. Toha, Pembuatan Sabun Lunak dari Minyak Goreng Bekas Ditinjau dari Kinetika Reaksi Kimia, Jurnal Teknik Kimia, 2:42-48, 2013.

[3] N. Paramita, A. Fahrurroji, and B. Wijianto, Optimasi Sabun Cair Ekstrak Etanol Rimpang Zingiber officinale Rosc. var. rubrum dengan Variasi Minyak Jarak dan Kalium Hidroksida, J. Trop. Pharm. Chem, 2:272-282, 2014.

[4] S.P. Perwitasari, Pemanfaatan Limbah Industri Kulit Sebagai Bahan Dasar Pembuatan Sabun, Jurnal Teknik Kimia, Vol. 5, pp. 425-427, 2011.

[5] C. Saleh, D. Tarigan, and R.A. Al-Idrus, Sintesis Sabun Lunak yang Mengandung Polihidroksi dari Minyak Biji Kakao (Theobroma cacao L.), Jurnal Kimia Mulawarman, Vol. 13, pp. 68-72, 2016.

[6] Y. Sinaga, Pemanfaatan Minyak Jelantah dalam Pembuatan Sabun Cair Transparan melalui Proses Saponifikasi KOH dengan Penambahan Essence Kulit Jeruk Nipis (Citrus aurantifolia), Thesis, Politeknik Negeri Sriwijaya, 2014. http://eprints.polsri.ac.id/id/eprint/1004.

[7] M. Renhard, Sabun Pencuci Piring Cair dengan Inovasi Penambahan Ekstrak Aloe Vera sebagai Anti Bakterial yang Bernilai Ekonomis Tinggi. Thesis, Universitas Sebelas Maret, 2016, https://eprints.uns.ac.id/id/eprint/29640.

[8] H. Soehatmo, T.H.P. Brotosudarmo, and L. Limantara, Pemanfaatan Klorofilin dalam Pembuatan Sabun Cuci Tangan Cair, Symbol, Vol.1, No.1, pp. 95-104, 2014.

[9] Susanty and S.A. Yudhistirani, Pengaruh Waktu Ekstraksi Daun Binahong (Anredera Cordifolia (Tenore) Steenis) Terhadap Kemampuan Daya Hambat Bakteri Escherichia Coli Untuk Pembuatan Hand Sanitizer, Konversi, Vol. 7 No.1, pp. 1-10, 2018.

[10]U. N. Uswah, A. Widyasanti, and Rosalinda, Perlakuan Bahan Baku Minyak Kelapa (Coconut Oil) dengan Variasi Konsentrasi Infused Oil Teh Putih (Camellia Sinensis) pada Pembuatan Sabun Cair, Jurnal Keteknikan Pertanian Tropis dan Biosistem, Vol. 7 No. 1, pp 67-77, 2019.

[11]R. Langingi, L. I. Momuat, and M. G. Kumaunang, Pembuatan Sabun Mandi Padat dari VCO yang Mengandung Karotenoid Wortel, Jurnal MIPA Unsrat Online, 2012, Vol. 1 No. 1, pp. 20-23.

[12]T. I. Sari, J. P. Kasih, and T. J. N. Sari, Pembuatan Sabun Padat dan Sabun Cair dari Minyak Jarak, Jurnal Teknik Kimia, 2010, Vol. 17 No. 1, pp 28-33.

[13]E. Widyasari, F. D. Yanuarsyah, and R. N. A. Adinata, Sabun Minyak Jelantah Ekstrak Daun Teh Hijau (Camellia sinensis) Pembasmi Staphylococcus aureus, Bioedukasi: Jurnal Pendidikan Biologi, 2018, Vol. 11 No. 2, pp 68-73.

[14] A. Widyasanti, A. T. Winaya, S. and Rosalinda, Pembuatan Sabun Cair Berbahan Baku Minyak Kelapa Dengan Berbagai Variasi Konsentrasi Ekstrak Teh Putih, Agrointek, 2019, Vol. 13 No. 2, pp 132-142.

[15] A.Widyasanti, A. Y. Rahayu, and S. Zein, Pembuatan Sabun Cair Berbasis Virgin Coconut Oil (VCO) Dengan Penambahan Minyak Melati (Jasminum sambac) Sebagai Essential Oil, Jurnal Teknotan, Vol. 11, No. 11, pp 1-10, 2017. 
[16]A, Widyasanti, Y. Qurratu'ain, and S. Nurjanah, Pembuatan Sabun Mandi Cair Berbasis Minyak Kelapa Murni (VCO) dengan Penambahan Minyak Biji Kelor (Moringa oleifera Lam), Chimica et Natura Acta, Vol. 5 No. 2, pp 77-84, 2017.

[17] S. A. Bidilah, O. Rumape, and E. Mohamad, Optimasi Waktu Pengadukan dan Volume KOH Sabun Cair Berbahan Dasar Minyak Jelantah, Jurnal Entropi, Vol. 12 No. 1, pp 55-60, 2017.

[18]F. Nurlina. Attamimi, Rosvina, dan I. Tomagola, Formulasi Sabun Cair Pencuci Tangan yang Mengandung Ekstrak Daun Kemangi (Occimum Basilicum L.), As-Syifaa, Vol. 05, No. 02, pp. 119-127, 2018.

[19] S. Wijana, D. Pranowo, dan M.Y. Taslimah, Penggandaan Skala Produksi Sabun Cair Dari Daur Ulang Minyak Goreng Bekas, Jurnal Teknologi Pertanian, Vol. 11 No. 2, pp. 114-122, 2010.G. Eason, B. Noble, and I.N. Sneddon, "On certain integrals of Lipschitz-Hankel type involving products of Bessel functions,” Phil. Trans. Roy. Soc. London, vol. A247, pp. 529-551, April 1955. 